CLINICAL STUDY

\title{
The role of ghrelin and ghrelin-receptor gene variants and promoter activity in type 2 diabetes
}

\author{
Edwin A Garcia, Peter King, Kally Sidhu, Hideko Ohgusu ${ }^{1}$, Andrew Walley ${ }^{2}$, Cecile Lecoeur ${ }^{5}$, Maria Gueorguiev, \\ Sahira Khalaf, Derek Davies ${ }^{4}$, Ashley B Grossman, Masayasu Kojima ${ }^{1}$, Stephan Petersenn ${ }^{3}$, Phillipe Froguel ${ }^{2,5}$ \\ and Márta Korbonits \\ Department of Endocrinology, Barts and the London School of Medicine and Dentistry, William Harvey Research Institute, Queen Mary University of \\ London, London EC1M 6BQ, UK, ${ }^{1}$ Molecular Genetics, Institute of Life Science, Kurume University, Kurume 1-1, Japan, ${ }^{2}$ Imperial College Genome Centre \\ and Genomic Medicine, Imperial College London, Hammersmith Hospital, London W12 ONN, UK, ${ }^{3}$ Division of Endocrinology, University of Duisburg- \\ Essen, 45122 Essen, Germany, ${ }^{4}$ London Research Institute Cancer Research UK, London WC2A 3PX, UK and ${ }^{5}$ Centre National de la Recherche \\ Scientifique UMR 8090-Institute of Biology, Pasteur Institute, 59000 Lille, France
}

(Correspondence should be addressed to M Korbonits; Email: m.korbonits@qmul.ac.uk)

\begin{abstract}
Background: Ghrelin and its receptor play an important role in glucose metabolism and energy homeostasis, and therefore they are functional candidates for genes carrying susceptibility alleles for type 2 diabetes.

Methods: We assessed common genetic variation of the ghrelin (GHRL; five single nucleotide polymorphisms (SNP)) and the ghrelin-receptor (GHSR) genes (four SNPs) in 610 Caucasian patients with type 2 diabetes and 820 controls. In addition, promoter reporter assays were conducted to model the regulatory regions of both genes.

Results: Neither GHRL nor GHSR gene SNPs were associated with type 2 diabetes. One of the ghrelin haplotypes showed a marginal protective role in type 2 diabetes. We observed profound differences in the regulation of the GHRL gene according to promoter sequence variants. There are three different GHRL promoter haplotypes represented in the studied cohort causing up to $45 \%$ difference in the level of gene expression, while the promoter region of GHSR gene is primarily represented by a single haplotype.

Conclusion: The GHRL and GHSR gene variants are not associated with type 2 diabetes, although GHRL promoter variants have significantly different activities.
\end{abstract}

European Journal of Endocrinology $161307-315$

\section{Introduction}

Type 2 diabetes is a disorder of glucose metabolism characterized by a spectrum of insulin resistance, obesity, and energy disturbances whose etiology resides in the interaction of genetic and non-genetic (environmental and lifestyle) factors (1). The ghrelin pathway has emerged over the last decade as a novel endocrine pathway involved in the control of feeding behavior and energy homeostasis, operating in parallel to the leptin and adiponectin circuits (2-5). Ghrelin is a 28 amino-acid peptide with a fatty acid chain modification on the N-terminal third amino acid by the ghrelin $\mathrm{O}$-acyltransferase enzyme (6). It has a widespread tissue expression but the main source of circulating ghrelin is the gastric mucosa (7). Ghrelin has a role in $\mathrm{GH}$ regulation (8) but in the recent years the majority of the data have shown its effects on appetite regulation via the hypothalamus (9) and the brain stem and influence on the peripheral metabolism, especially the carbohydrate and lipid metabolism (10). Ghrelin is a factor involved in meal initiation which acts on the hypothalamus via the ghrelin receptor (11). Ghrelin and obestatin are encoded by the same gene and propeptide, but different post-translational processes generate two peptides with opposing functions; obestatin was originally suggested to counteract the effects of ghrelin on food intake (5), although controversy has recently arisen regarding the function of obestatin (12).

Ghrelin and its receptor are functional candidates for type 2 diabetes: i) ghrelin influences glucose homeostasis, hyperglycemia caused by $50 \mathrm{~g}$ glucose administrated either orally or i.v. suppressed ghrelin levels and ghrelin is lowered by a euglycemic hyperinsulinemic clamp suggesting that insulin responsiveness is a major regulator of ghrelin levels in both human and rodents (13), ii) it is expressed in the pancreatic islets and ghrelin cells replace insulin cells in case of abnormal $\beta$-cell development (14), and iii) lack of ghrelin can rescue the diabetic phenotype of the leptin-deficient mouse (15). The ghrelin and ghrelinreceptor genes have been studied in the context of 
obesity and type 2 diabetes, but any putative associations have been controversial (16-22). It has been difficult to tease out these conditions due to the fact that obesity is an independent risk factor for type 2 diabetes, and it is likely that different pathophysiological mechanisms occur in non-obese and obese subjects with type 2 diabetes (23).

We have assessed the genetic variation of the ghrelin and ghrelin-receptor genes in a French population in order to study the role of these genes in type 2 diabetes, and aimed to model the impact of promoter variations in both genes using luciferase reporter assays in two well-established cell models, GH3 somatolactotroph rat cell line for the ghrelin receptor promoter (24) and human medullary thyroid tumor (MTT) cell line for the ghrelin promoters (25), under different hormonal challenges previously reported to modulate gene expression $(24,25)$. We identified a protective haplotype for type 2 diabetes in the ghrelin gene and established that this haplotype is linked to a promoter region with reduced activity.

\section{Materials and methods}

\section{Subjects}

A total of 610 unrelated diabetic individuals were drawn from families with at least two affected probands who participated in a French public campaign in 1990 entitled '200 families to overcome diabetes' (see details in (26)). The diabetic phenotype was defined in the light of the clinical report and the results of the latest measurements for fasting and/or oral glucose-tolerance test according to the established American Diabetes Association criteria for type 2 diabetes (Expert Committee on the Diagnosis and Classification of Diabetes Mellitus, 1997; 27): 'diabetic' (DM) when receiving oral hypoglycemic agents or insulin 1 year after the diagnosis or when fasting glycemia was $7 \mathrm{mmol} / \mathrm{l}$ or glycemia $11.1 \mathrm{mmol} / \mathrm{l} 2 \mathrm{~h}$ after an oral glucose load. The 820 controls were selected from the SUVIMAX study, an 8-year prospective primary prevention trial assessing the impact of anti-oxidant and minerals in cardiovascular disease and cancer (28) and from the Fleurbaix Laventie Ville Santé study, a cross-sectional survey of the nutritional and behavioral characteristics of the free-living population (29). Clinical details are shown in Table 1.

Genotyping The single nucleotide polymorphisms (SNPs) A-604G (rs27647), C-501A (rs26802), C247A (rs696217), A265T (rs4684677), and G62T (rs35683) in the ghrelin gene (GHRL) and the SNPs Ins/Del (rs10618418a), A477G (rs572169), C607G (rs2232169), and C658T (rs2232165) in the ghrelin-receptor gene (GHSR) were genotyped with matrix-assisted laser desorption/ionization time of flight mass spectrometry following the manufacturer's
Table 1 Clinical characteristics.

\begin{tabular}{|c|c|c|c|}
\hline Variable & $\begin{array}{l}\text { Control } \\
(n=820)\end{array}$ & $\begin{array}{l}\text { Case } \\
(n=610)\end{array}$ & $P$ value \\
\hline Gender (M/F) & $333 / 487$ & $342 / 268$ & $<0.001$ \\
\hline BMI $\left(\mathrm{kg} / \mathrm{m}^{2}\right)$ & 24.2 (3.6) & $26.8(3.5)$ & $<0.001$ \\
\hline Age (years) & & & $<0.001$ \\
\hline Median & 52 & 60 & \\
\hline Interquantile range & $47-58$ & $52-57$ & \\
\hline Age of diagnosis & - & $45.2(11.5)$ & - \\
\hline Waist $(\mathrm{cm})$ & & & $<0.001$ \\
\hline Median & 83 & 96 & \\
\hline Interquantile range & $72-92$ & $87-103$ & \\
\hline Hip (cm) & & & $<0.001$ \\
\hline Median & 99 & 102 & \\
\hline Interquantile range & $95-103$ & $96-109$ & \\
\hline Basal glucose $(\mathrm{mM} / \mathrm{l})$ & & & $<0.001$ \\
\hline Median & 5.3 & 9.0 & \\
\hline Interquantile range & $5.0-5.7$ & $7.0-11.3$ & \\
\hline
\end{tabular}

recommendations (Sequenom, San Diego, CA, USA). A small PCR fragment of not more than $100 \mathrm{bp}$ flanking the variant loci becomes the template of a minisequence reaction where a third primer adjacent to the variant base by one or two nucleotides of the $3^{\prime}$ side of the sequence primer is extended by a thermostable sequenase in an admixture of dNTPs and ddNTPs. After some treatments to purify the sequencing primers extended, the SNP scoring is determined by the molecular weight of each sequence-extended primer. Figure 1 displays the SNPs genotyped in this study for both genes in the context of the HAPMAP study. The selected SNPs cover most of the genetic variation and the justification for selection has been described in previous studies for GHSR (30) and for GHRL (31) and the assay has been validated in our previous studies by fluorescence sequence in both directions (30). These variants are haplotype tagging SNPs (default $r^{2}>0.8$ ) following the algorithms implemented in Haploview (32) and TAGGER (33).

Plasmids The wild-type (WT) GHRL promoter cloned into pGL3 plasmid (Promega) has been developed and previously characterized in MTT cells (25) and the C-604G, C-501A, T-227C, and C-36T variations (34) were incorporated into the pGL3-GHRL plasmid using site-directed mutagenesis with QuikChange (Stratagene, La Jolla, CA, USA). The WT GHSR promoter cloned into pGL3 has been previously characterized in pituitary cells (24), and the A-959C, A-794T, C-786T, A-756G, and C-498T variations were incorporated into the pGL3-GHSR plasmid (34). These promoter variants were determined in 70 obese children for ghrelin and 60 short children for GHSR as part of a SNP discovery study (Table 2). Sequence confirmation using an ABI3700 (Perkin Elmer, Warrington, UK) was performed on both strands for each variant. Some of these SNPs, two in the GHRL and five in the GHSR receptor have not been annotated in HAPMAP and they are highlighted in Fig. 1. 

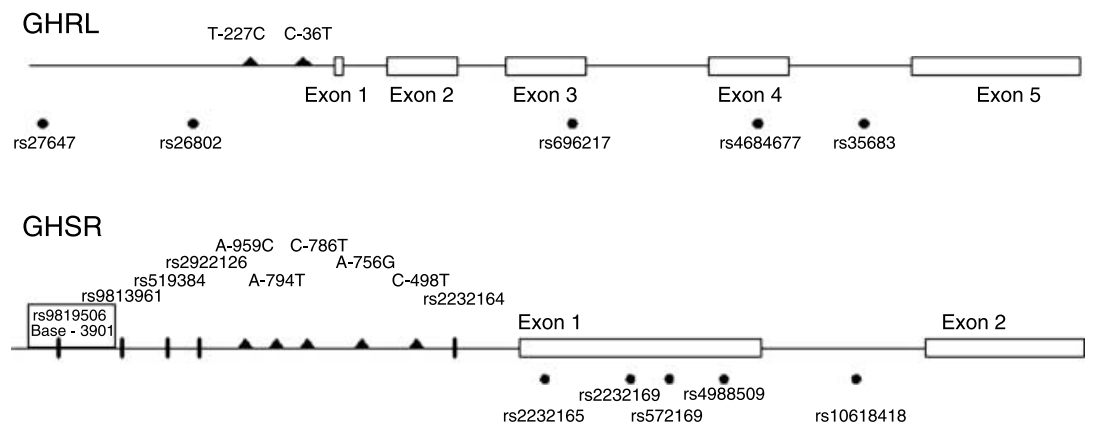

Figure 1 Ghrelin and ghrelin-receptor gene maps annotation based on HAPMAP (www.hapmap.org). Circles, SNPs genotyped in this study. Triangles, SNPs identified by sequencing in 70 French obese children and 60 short children for GHSR without annotation in HAPMAP.
Cell culture Cells were seeded and maintained in $75 \mathrm{~cm}^{2}$ flasks in medium as follows: GH3 somatolactotroph mouse cells in DMEM (Gibco) and human MTT cell line in a 50:50 admixture DMEM/F12K, supplemented with $10 \%$ serum and antibiotics (penicillin/streptomycin) at $37^{\circ} \mathrm{C}, 5 \% \mathrm{CO}_{2}$ humidified atmosphere.

Transient transfection and luciferase assay analysis Fifty thousand cells were plated in 96-well white-wall clear-bottom plates (Costar 3610, Fisher Scientific, Loughborough, UK) and were transfected with $12 \mathrm{ng}$ test plasmid and $1.2 \mathrm{ng}$ pRL renilla control plasmid (Promega) using $0.5 \mu$ l Lipofectamine 2000 (Invitrogen) in a volume of $50 \mu \mathrm{l}$ unsupplemented media. After $3 \mathrm{~h}$, media was changed to $20 \%$ FBS/antibiotic free media and the cells were incubated for $24 \mathrm{~h}$. Basal luciferase activity was measured at $24 \mathrm{~h}$.

Cells were hormone treated $24 \mathrm{~h}$ later after liposome transfection with estradiol $\left(\mathrm{E}_{2} ; 10^{-9} \mathrm{M}\right)$, triiodothyronine $\left(\mathrm{T}_{3} ; 10^{-9} \mathrm{M}\right)$, and hydrocortisone $\left(10^{-7} \mathrm{M}\right)$ and harvested $8 \mathrm{~h}$ later in $20 \mu \mathrm{l}$ passive lysis buffer (Promega) for luciferase experiments. The control cells were treated in parallel with the appropriate vehicle: ethanol $(1 \mathrm{mM})$ for hydrocortisone and $\mathrm{E}_{2}$ and etha$\mathrm{nol} / \mathrm{HCl}\left(6 \times 10^{-6} \mathrm{M} / 1.1 \times 10^{-2} \mathrm{M}\right)$ for $\mathrm{T}_{3}$. Luciferase and renilla activities were measured using the Dual Luciferase assay (Promega) in a plate-reader fitted with two injectors (Victor 1420, Perkin Elmer). Background luminescence was measured for $5 \mathrm{~s}$ and the luciferase and renilla activities were measured for $10 \mathrm{~s}$. Each experiment was performed in duplicate. Data are expressed as the luciferase/renilla activity ratio (25).

\section{Statistical analysis}

Normal distributed variables are shown as mean and S.D. The $\chi^{2}$-test applied for categorical variables. Non-normal distributed variables are presented as the median and interquantile range and the non-parametric Kruskal-Wallis test applied when testing quantitative variables using the platform $\mathrm{R}$ version 2.6.2. Hardy-Weinberg equilibrium (HWE) and association analysis were performed with the software Thesias (Paris, France) (35). For the functional assay data, ANOVA was used to test the differences between haplotypes and Tukey's post hoc test (GraphPad Prism, La Jolla, CA, USA).

Table 2 Haplotypes in the promoter of the ghrelin and ghrelin-receptor gene observed in 70 French obese children for GHRL and 60 idiopathic short children for GHSR.

\begin{tabular}{|c|c|c|c|c|c|c|c|}
\hline & A-604G & & C-501A & & $\mathrm{T}-227 \mathrm{C}$ & C-36T & Frequency \\
\hline \multicolumn{8}{|c|}{ GHRL promoters } \\
\hline WT & G & & A & & $\mathrm{T}$ & C & 0.39 \\
\hline GHRL2 & A & & C & & $\mathrm{T}$ & C & 0.28 \\
\hline GHRL3 & $\bar{A}$ & & $\bar{A}$ & & $\mathrm{~T}$ & C & 0.26 \\
\hline GHRL4 & $\overline{\mathrm{G}}$ & & C & & $\mathrm{T}$ & C & 0.04 \\
\hline GHRL5 & A & & $\bar{A}$ & & C & C & 0.02 \\
\hline \multirow[t]{2}{*}{ GHRL6 } & $\underline{\bar{A}}$ & & $\underline{\mathrm{C}}$ & & $\overline{\mathrm{T}}$ & $\underline{T}$ & 0.01 \\
\hline & A-959C & A-794T & & C-786T & A-756G & C-498T & Frequency \\
\hline \multicolumn{8}{|c|}{ GHSR promoters } \\
\hline WT & $A$ & $A$ & & C & A & $\mathrm{C}$ & 0.96 \\
\hline GHSR2 & A & A & & C & A & $\mathrm{T}$ & 0.007 \\
\hline GHSR3 & A & A & & $\mathrm{T}$ & $\mathrm{G}$ & $\dot{\bar{C}}$ & 0.01 \\
\hline GHSR4 & A & $\underline{T}$ & & $\overline{\mathrm{C}}$ & $\bar{A}$ & $\mathrm{C}$ & 0.02 \\
\hline
\end{tabular}

Underlined characters indicates mutated site to get the haplotype. 
Table 3 Single nucleotide polymorphism association analysis of the ghrelin gene.

\begin{tabular}{|c|c|c|c|c|c|c|c|}
\hline Loci & $\begin{array}{c}\text { Allele/ } \\
\text { genotype }\end{array}$ & Control & Case & HWE & $\begin{array}{c}\text { Control } \\
\text { genotype } \\
\text { frequencies }\end{array}$ & $\begin{array}{c}\text { Case } \\
\text { genotype } \\
\text { frequencies }\end{array}$ & OR 95\% Cl \\
\hline A-604G & $A A$ & 198 & 187 & \multirow{3}{*}{0.02} & 0.36 & 0.35 & \multirow{3}{*}{$0.94(0.80-1.11)$} \\
\hline \multirow[t]{2}{*}{ rs27647 } & AG & 235 & 248 & & 0.43 & 0.46 & \\
\hline & GG & 112 & 104 & & 0.21 & 0.19 & \\
\hline C-501A & $\mathrm{CC}$ & 87 & 59 & \multirow{3}{*}{0.98} & 0.11 & 0.10 & \multirow{3}{*}{$0.89(0.76-1.03)$} \\
\hline \multirow[t]{2}{*}{ rs26802 } & CA & 353 & 249 & & 0.45 & 0.43 & \\
\hline & AA & 338 & 265 & & 0.43 & 0.46 & \\
\hline C247A & CC & 633 & 523 & \multirow{3}{*}{0.48} & 0.85 & 0.87 & \multirow{3}{*}{$1.15(0.87-1.51)$} \\
\hline rs696217 & $\mathrm{CA}$ & 108 & 75 & & 0.15 & 0.13 & \\
\hline Leu72Met & AA & 2 & 2 & & 0.00 & 0.00 & \\
\hline A265T & $\mathrm{TT}$ & 2 & 3 & & 0.00 & 0.01 & \\
\hline rs4684677 & TA & 81 & 65 & \multirow[t]{2}{*}{0.9} & 0.10 & 0.11 & \multirow[t]{2}{*}{$1.07(0.79-1.45)$} \\
\hline GIn90Leu & AA & 689 & 509 & & 0.89 & 0.88 & \\
\hline G62T & GG & 171 & 156 & \multirow{3}{*}{0.08} & 0.25 & 0.27 & \multirow{3}{*}{$1.02(0.88-1.18)$} \\
\hline \multirow[t]{2}{*}{ rs35683 } & GA & 337 & 263 & & 0.48 & 0.46 & \\
\hline & TT & 187 & 156 & & 0.27 & 0.27 & \\
\hline
\end{tabular}

\section{Results}

\section{Case-control study results}

A French cohort comprising 610 subjects with type 2 diabetes and 820 controls was studied (Table 1) and genotyped for five SNPs in the ghrelin gene and four SNPs in the ghrelin-receptor gene. All of the SNPs were in HWE except the rs27647 that was not included in the haplotype analysis. No significant differences were observed in allele frequencies between the type 2 diabetes and the control group either for the ghrelin gene (Table 3) or for the ghrelin-receptor gene (Table 4). No significant differences were found under recessive, dominant, multiplicative, and general models for both genes. The SNP combination within the GHRL rs26802 - rs696217 - rs4684677 rs35683 was marginally associated and the haplotype AAAG was found to be protective for type 2 diabetes after adjustment for gender, age, and body mass index (BMI) 0.64 (0.41-0.98) odds ratio (OR) 95\% confidence interval (CI) $P=0.044$ (Table 5).
No association was observed between haplotypes of the ghrelin-receptor gene in the entire cohort with type 2 diabetes (Table 5).

\section{Basal luciferase activity of the ghrelin and GHSR promoters in GH3 cells}

SNPs in the promoter region of ghrelin and ghrelinreceptor gene were studied with luciferase assay.

Ghrelin The promoter of the ghrelin gene comprises six haplotypes, and we created constructs according to each of these haplotypes (the WT-GHRL1 and GHRL2-6). Three of these six haplotypes (WT-GHRL1, GHRL2 and GHRL3) were observed with a frequency $>5 \%$. The GHRL3 promoter haplotype is linked with the AAAG GHRL gene haplotype. The luciferase activity of the different promoter variants significantly differed from the most common WT-GHRL1 haplotype (Fig. 2). The WT-GHRL1 promoter-driven basal luciferase activity was $0.054 \pm 0.0002$ (s.E.M.); GHRL2 showed

Table 4 Single nucleotide polymorphism association analysis of the ghrelin receptor gene.

\begin{tabular}{|c|c|c|c|c|c|c|c|}
\hline & $\begin{array}{c}\text { Allele/ } \\
\text { genotype }\end{array}$ & Control & Case & HWE & $\begin{array}{c}\text { Control } \\
\text { genotype } \\
\text { frequencies }\end{array}$ & $\begin{array}{c}\text { Case } \\
\text { genotype } \\
\text { frequencies }\end{array}$ & OR $95 \% \mathrm{Cl}$ \\
\hline In/Del & II & 37 & 40 & & 0.05 & 0.06 & \\
\hline \multirow[t]{2}{*}{ rs10618418 } & ID & 294 & 231 & \multirow[t]{3}{*}{0.82} & 0.38 & 0.33 & \multirow[t]{2}{*}{$0.93(0.78-1.10)$} \\
\hline & DD & 440 & 419 & & 0.57 & 0.61 & \\
\hline A577G & GG & 403 & 324 & & 0.54 & 0.53 & \multirow{2}{*}{$1.01(0.85-1.20)$} \\
\hline & $\mathrm{AA}$ & 61 & 43 & & 0.08 & 0.07 & \\
\hline C607G & $\mathrm{CC}$ & 740 & 661 & & 0.97 & 0.96 & \multirow{3}{*}{$0.84(0.49-1.42)$} \\
\hline \multirow[t]{2}{*}{ rs2232169 } & $\mathrm{CG}$ & 25 & 29 & 0.41 & 0.03 & 0.04 & \\
\hline & GG & 1 & 0 & & 0.00 & 0.00 & \\
\hline C658T & $\mathrm{CC}$ & 741 & 605 & & 0.94 & 0.94 & \multirow{3}{*}{$1.11(0.73-1.70)$} \\
\hline \multirow[t]{2}{*}{ rs2232165 } & CT & 50 & 36 & 0.64 & 0.06 & 0.06 & \\
\hline & $\mathrm{TT}$ & 1 & 1 & & 0.00 & 0.00 & \\
\hline
\end{tabular}


Table 5 Haplotype analysis of the ghrelin and GHSR gene. There is no value for the haplotype ACAT/DACC as it is taken as reference.

\begin{tabular}{lccc}
\hline \multicolumn{2}{c}{$\begin{array}{c}\text { Frequency in } \\
\text { controls }\end{array}$} & $\begin{array}{c}\text { Frequency in } \\
\text { cases }\end{array}$ & $\begin{array}{c}\text { Adjusted }{ }^{\mathrm{a}} \text { OR } \\
\mathbf{9 5 \%} \mathbf{~ C l}\end{array}$ \\
\hline Haplotype GHRL & & \\
rs26802; rs696217; rs4684677; rs35683 & \\
ACAT & 0.40 & 0.42 & - \\
CCAG & 0.23 & 0.22 & $0.97(0.78-1.21)$ \\
ACAG & 0.15 & 0.15 & $0.98(0.75-1.28)$ \\
CCAT & 0.09 & 0.07 & $0.71(0.47-1.08)$ \\
AAAG & 0.06 & 0.04 & $0.64(0.41-0.98)$ \\
ACTG & 0.05 & 0.05 & $1.08(0.71-1.64)$ \\
Haplotype GHSR & & & \\
rs10618418; rs572169; rs2232169; rs2232165 & \\
DACC & 0.45 & 0.46 & - \\
DGCC & 0.29 & 0.29 & $0.97(0.78-1.22)$ \\
IACC & 0.24 & 0.23 & $0.96(0.75-1.23)$ \\
DAGT & 0.02 & 0.02 & $0.63(0.31-1.25)$ \\
\hline
\end{tabular}

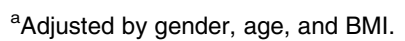

$36 \%$ increased activity $(0.074 \pm 0.0005, P<0.01)$, and GHRL3 45\% decreased activity (0.0029 \pm 0.0007 , $P<0.001$, Fig. 2; overall $P<0.0001)$.

Ghrelin receptor The haplotypes of the ghrelinreceptor gene displayed less variability due to the high level of linkage disequilibrium. One common haplotype (WT-GHSR1) with a frequency of $96 \%$ and three other minor haplotypes were studied with luciferase assay. Statistical significant differences were observed in the basal luciferase activity driven by the promoter variants of the GHSR gene. The basal luciferase activity of the WT-GHSR 1 promoter was $0.048 \pm 0.003 ;$ GHSR $20.110 \pm 0.007, \quad(P<0.01$, compared with WT-GHSR 1$)$; GHSR $30.013 \pm 0.002$, $(P<0.01)$ and GHSR4 0.083 $\pm 0.003,(P<0.01$, Fig. 2 , overall $P<0.0001)$.

\section{Ghrelin and ghrelin receptor promoter activity in response to hormonal stimulation}

Ghrelin Hydrocortisone treatment of GH3 cells bearing the six different ghrelin promoter haplotypes showed that GHRL5 had the lowest level of luciferase activity (Fig. 3). $E_{2}$ caused no significant difference in the luciferase activity of the six promoter haplotypes, while $\mathrm{T}_{3}$ stimulated the activity of GHRL6 significantly more than the activity of GHRL1. In MTT cells hydrocortisone and $\mathrm{T}_{3}$ did not cause a difference in the activity of the promoters, while $\mathrm{E}_{2}$ was found to induce differential expression in luciferase activity, and the post hoc analysis reveals that the GHRL2 promoter differs significantly with GHRL3, GHRL4, and GHRL6.

Ghrelin receptor In $\mathrm{GH} 3$ cells hydrocortisone and $\mathrm{T}_{3}$ had similar effect on the four different GHSR promoter haplotypes, while $\mathrm{T}_{3}$ had a significantly stronger effect
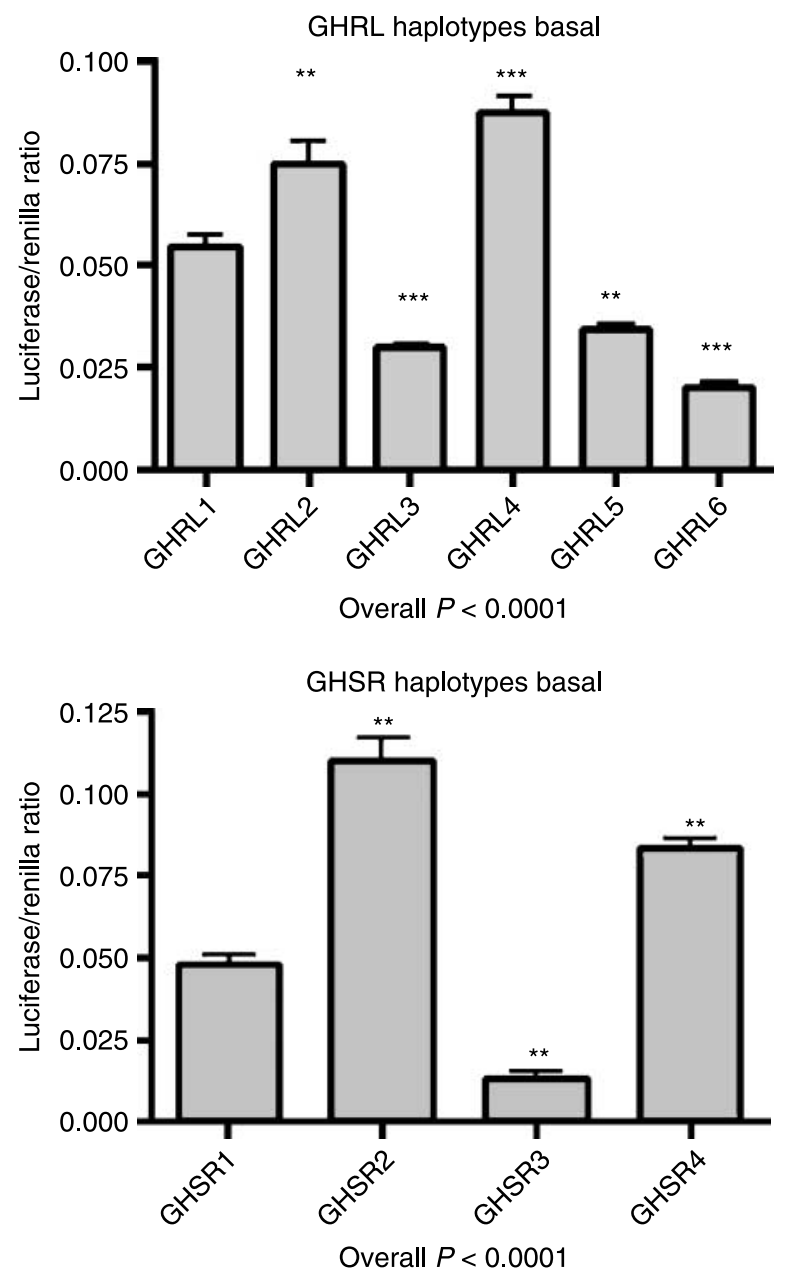

Figure 2 Basal luciferase activity driven by the ghrelin and ghrelin receptor promoters is shown in GH3 cells. Basal activity of luciferase was normalized by renilla at $24 \mathrm{~h}$ after transfection. GHRL1 and GHSR1 are the wild-type haplotypes for the ghrelin and GHSR respectively. ${ }^{\star \star} P<0.01$ and ${ }^{* \star \star} P<0.001$.

on the WT-GHSR 1 than on GHSR3 and GHSR4 (Fig. 4). In MTT cells hydrocortisone stimulated GHSR2 more than the WT GHSR1, while $\mathrm{E}_{2}$ and $\mathrm{T}_{3}$ caused no difference in their activation.

\section{Discussion}

Polymorphisms of the ghrelin or the ghrelin-receptor gene were not associated with type 2 diabetes in a French population using a case-control approach comprising 610 type 2 diabetic subjects and 820 controls. A borderline protective association was observed with one of the ghrelin haplotypes. Nevertheless, when the regulatory regions of these genes were modeled in a luciferase reporter assay significant differences were observed in the promoter activities of the ghrelin gene. The relevance of these findings in the 

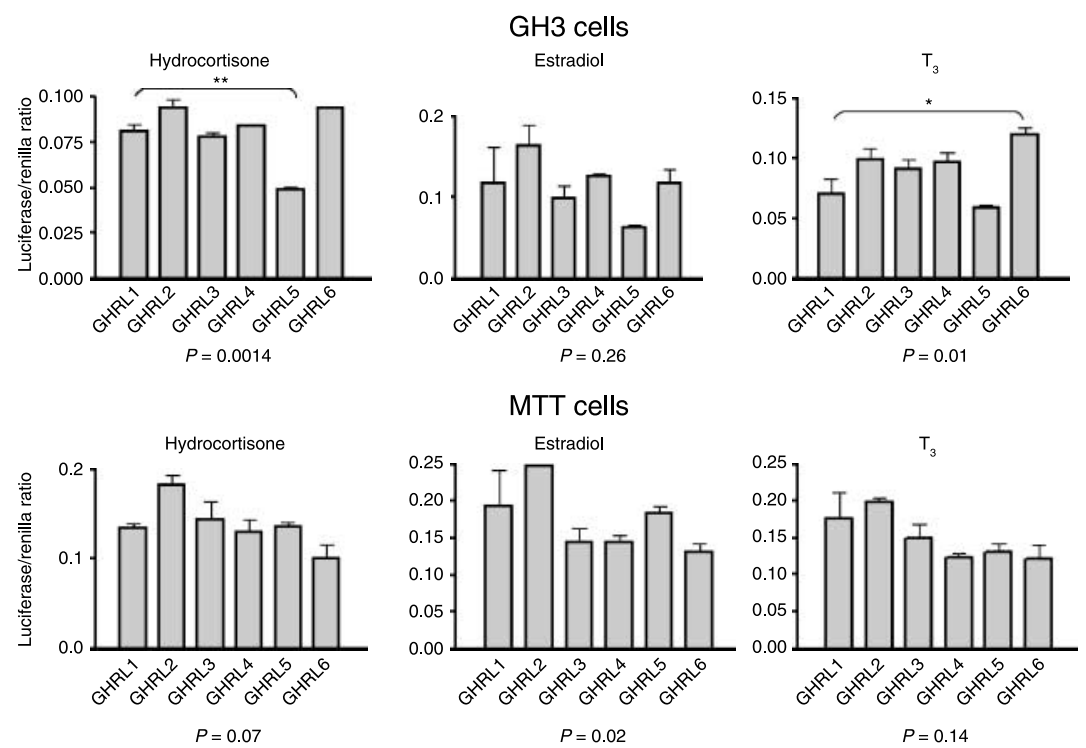

Figure 3 Luciferase activity in $\mathrm{GH} 3$ and MTT cells transiently expressing GHRL promoters. After $24 \mathrm{~h}$ post-transfection, cells were treated with hormones $\left(10^{-7} \mathrm{M}\right.$ hydrocortisone, $10^{-9} \mathrm{M}$ estradiol and $10^{-9} \mathrm{M}$ triiodothyronine $\left(\mathrm{T}_{3}\right)$ ) and harvested $8 \mathrm{~h}$ later. ${ }^{\star} P<0.05,{ }^{\star \star} P<0.01$. context of type 2 diabetes is not clear due to the fact that our population study did not identify a genetic association with this trait.

The luciferase activity driven by one of the GHRL gene promoter haplotypes, assigned in this study as GHRL3, was found to be $45 \%$ less active when compared with the most common regulatory haplotype (WT-GHRL1) under basal conditions in pituitary cells. This suggests that carrying the GHRL3 promoter will lead to reduced ghrelin activity, which supports data from leptin/ghrelin double-knockout animals where the lack of ghrelin rescued the diabetic phenotype of the leptin-deficient mice (15). The 247A/72Met allele has been associated with protection against fat accumulation and associated metabolic disturbances (18). However, other studies found an earlier onset of obesity and early blunted response to insulin after a glucose tolerance test in carriers of the $72 \mathrm{Met}$ allele ( 16 , 17). In the context of the present study, no association was found for the C247A polymorphism and type 2 diabetes. Therefore, clinical studies have been contradictory regarding the role of the 247A/72Met in type 2 diabetes-associated abnormalities.

The ghrelin-receptor gene was not associated with type 2 diabetes; based on the observation that neither differences in both allele and genotype nor differences in haplotype frequencies between cases and controls were identified. This gene has been found associated with
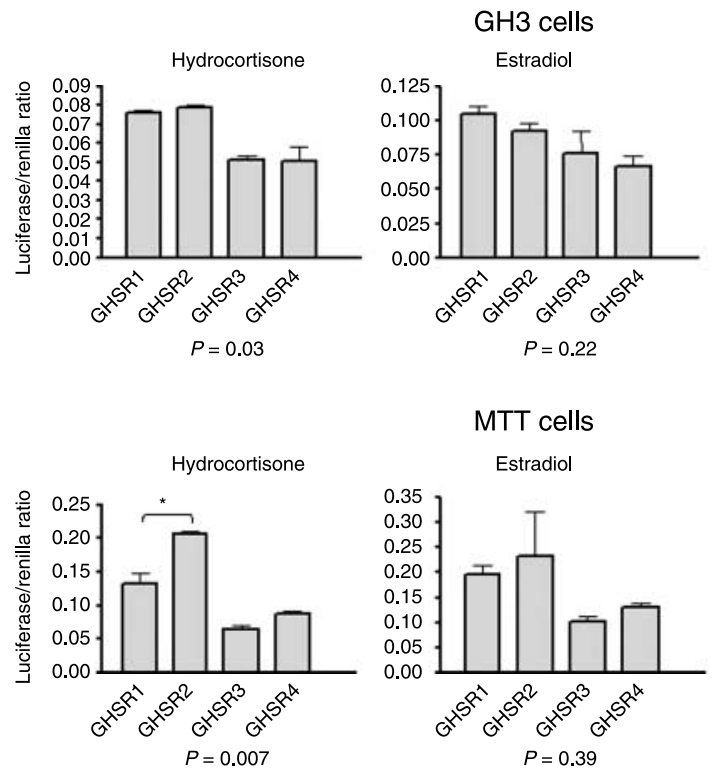
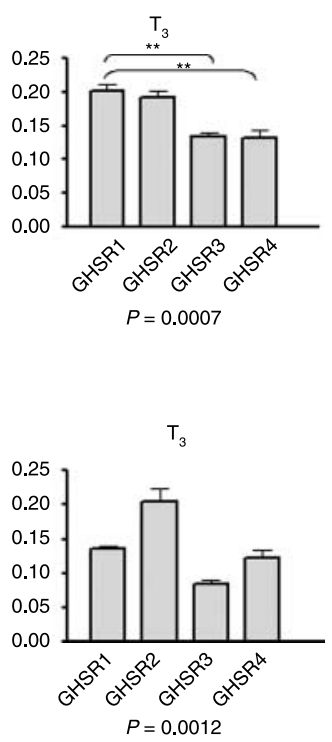

Figure 4 Luciferase activity in GH3 and MTT cells transiently expressing GHSR promoters. After $24 \mathrm{~h}$ post-transfection, cells were treated with hormones $\left(10^{-7} \mathrm{M}\right.$ hydrocortisone, $10^{-9} \mathrm{M}$ estradiol and $10^{-9} \mathrm{M}$ triiodothyronine) and harvested $8 \mathrm{~h}$ later. ${ }^{\star} P<0.05,{ }^{\star \star} P<0.01$. 
obesity in a study using the transmission disequilibrium test and a case-control approach in subjects with a $\mathrm{BMI}>32 \mathrm{~kg} / \mathrm{m}^{2}$ and non-obese with a BMI $<28 \mathrm{~kg} / \mathrm{m}^{2}$ (21). After applying this BMI definition to our population, we cannot replicate this association with obesity (21), although it needs to be emphasized that our population was selected based on the presence of type 2 diabetes and not obesity. Furthermore, evidence of the GHSR gene role in obesity was presented recently (36): a variation $\sim 3.5 \mathrm{~kb}$ downstream in the promoter of GHSR assisted in the identification of subjects that could benefit from dietary interventions (this SNP is boxed in Fig. 1). Homozygotes carrying the CC allele, $10 \%$ of the cohort studied, benefited most in terms of weight loss after 3 years dieting/exercise intervention. However, it is uncertain what the impact is of this variant in the etiology of type 2 diabetes. It would be attractive to genotype this variant in a group of diabetic subjects that benefited most of dietary interventions; this is an issue that can be explored in prospective studies. Our results should be interpreted with caution due to the fact that binary outcomes, presence or absence of the disease methodologically differ from those studies using quantitative intermediate phenotypes as proxies for disease status. Efforts were made in the current study to translate our findings in the context of previous studies using their definitions, and this is a valid approach to justify replication and the role of a gene in a disease of complex nature; however, nonstatistical significant findings were found.

The WT GHRL and GHSR promoters have been previously described $(24,25)$. The aim of these experiments was to test if common variations found in the promoter regions of these genes have an impact on gene expression. Basal activity of the GHRL promoter was characterized in MTT cells and in human hepatoma cell lines (HepG2) (25) and we now present data on its hormonal modulation in GH3 and MTT cells. The GHRL gene has three common haplotypes observed in human populations with a frequency of 0.39 for GHRL1, 0.28 for GHRL2, and 0.26 for GHRL3 respectively. A significantly lower activity was observed for the GHRL3 promoter haplotype (AATC) and this haplotype drives the AAAG gene haplotype observed with a frequency of $6 \%$ in type 2 diabetes and $4 \%$ in the control cohort. While basal GHRL promoter haplotype luciferase activities were different (Fig. 2), they all responded similarly to hormonal challenge (Fig. 3). For example, the GHRL3 and GHRL6 haplotypes have low basal activity but normal response to hormonal stimulation in both cell-type models, suggesting that the two loci T-501A and C-36T, where they differ from WT-GHRL1 are crucial in gene expression regulation profiles in vivo. The luciferase activity values for both genes were higher in MTT than in GH3 cells suggesting a differential regulation of the WT promoter depending on the cell line.
In our populations, GHSR has one unique promoter haplotype commonly observed while the others run in a lower frequency below 5\%. The GHSR WT promoter has been characterized in $\mathrm{GH} 4$ cells with thyroid hormone and $\mathrm{E}_{2}$ (stimulatory) and glucocorticoids (inhibitory) effects on luciferase activity (24). In this study using the GH3 cell line and the MTT cells, we reproduced this observation for $\mathrm{E}_{2}$ and $\mathrm{T}_{3}$ but we observed stimulatory effects for hydrocortisone. The discrepancy between the two studies can be explained by different cell lines and experimental design. The rare GHSR2 and GHSR 4 promoters were shown to be inhibited by hydrocortisone. Our findings are concordant with a tissue-specific regulation of ghrelin and its receptor that can be influenced by common genetic variation in the regulatory regions of these genes. The functional assessment of SNPs on transcriptional regulation in vivo is at present a difficult task; in vitro assay of proteinDNA interaction and plasmid reporter gene expression are not suitable for a genome wide approach, and new approaches have also been proposed for this aim (37). We speculate that SNPs in the regulatory region of a gene can be one of the underlying modulators linking the association between a gene and a complex trait.

A limitation in this study is the number of subjects that would affect statistical power, therefore we attained for a genetic association and the role of genetic variation in the regulatory regions of these genes with haplotypes and not with single genetic variants. Power calculations for differences in proportion in a biallelic system (SNPs) indicates that with the cohorts studied a difference of 0.06 in allele frequencies can be identified with an $\alpha$ value of 0.05 and a $\beta$ value of 0.2 . While this study shows minor evidence for the genetic role of these genes in type 2 diabetes, the functional consequences conferred by nucleotide variations on these genes are very deterministic. The likelihood of a false negative because of low statistical power is plausible nevertheless, neither GHRL nor the GHSR have been identified as hits for type 2 diabetes in genome-wide association studies or have been included into the genetic risk score $(38,39)$ recently proposed for prediction models of type 2 diabetes risk.

In summary, this study found no association of the ghrelin and ghrelin-receptor gene with type 2 diabetes, but variants in the regulatory region of these genes cause profound differences in gene expressions.

\section{Declaration of interest}

There is no conflict of interest that could be perceived as prejudicing the impartiality of the research reported.

\section{Funding}

This work was supported by Diabetes UK (Grant number: RD02/0002376). 


\section{References}

1 Report of the Expert Committee on the Diagnosis and Classification of Diabetes Mellitus. Diabetes Care 200326 S5-S20.

2 Howard AD, Feighner SD, Cully DF, Arena JP, Liberator PA, Rosenblum CI, Hamelin M, Hreniuk DL, Palyha OC, Anderson J, Paress PS, Diaz C, Chou M, Liu KK, McKee KK, Pong SS, Chaung LY, Elbrecht A, Dashkevicz M, Heavens R, Rigby M, Sirinathsinghji DJ, Dean DC, Melillo DG, Patchett AA, Nargund R, Griffin PR, DeMartino JA, Gupta SK, Schaeffer JM, Smith RG \& Van der Ploeg LH. A receptor in pituitary and hypothalamus that functions in growth hormone release. Science $1996 \mathbf{2 7 3} 974-977$.

3 Kojima M, Hosoda H, Date Y, Nakazato M, Matsuo H \& Kangawa K. Ghrelin is a growth-hormone-releasing acylated peptide from stomach. Nature $1999 \mathbf{4 0 2} 656-660$.

4 Tschop M, Smiley DL \& Heiman ML. Ghrelin induces adiposity in rodents. Nature $2000 \mathbf{4 0 7} 908-913$.

5 Zhang JV, Ren PG, Avsian-Kretchmer O, Luo CW, Rauch R, Klein C \& Hsueh AJ. Obestatin, a peptide encoded by the ghrelin gene, opposes ghrelin's effects on food intake. Science $2005 \mathbf{3 1 0}$ 996-999.

6 Yang J, Brown MS, Liang G, Grishin NV \& Goldstein JL. Identification of the acyltransferase that octanoylates ghrelin, an appetite-stimulating peptide hormone. Cell 2008132 387-396.

7 Korbonits M, Goldstone AP, Gueorguiev M \& Grossman AB. Ghrelin - a hormone with multiple functions. Frontiers in Neuroendocrinology 200425 27-68.

8 Nass R, Farhy LS, Liu J, Prudom CE, Johnson ML, Veldhuis P. Pezzoli SS, Oliveri MC, Gaylinn BD, Geysen HM \& Thorner MO. Evidence for acyl-ghrelin modulation of growth hormone release in the fed state. Journal of Clinical Endocrinology and Metabolism $2008931988-1994$.

9 Kola B \& Korbonits M. Shedding light on the intricate puzzle of ghrelin's effects on appetite regulation. Journal of Endocrinology 2009202 1-9.

10 Higgins SC, Gueorguiev M \& Korbonits M. Ghrelin, the peripheral hunger hormone. Annals of Medicine 200739 116-136.

11 Cummings DE, Purnell JQ, Frayo RS, Schmidova K, Wisse BE \& Weigle DS. A preprandial rise in plasma ghrelin levels suggests a role in meal initiation in humans. Diabetes $2001501714-1719$.

12 Garg A. The ongoing saga of obestatin: is it a hormone? Journal of Clinical Endocrinology and Metabolism 200792 3396-3398.

13 McCowen KC, Maykel JA, Bistrian BR \& Ling PR. Circulating ghrelin concentrations are lowered by intravenous glucose or hyperinsulinemic euglycemic conditions in rodents. Journal of Endocrinology 2002175 R7-11.

14 Prado CL, Pugh-Bernard AE, Elghazi L, Sosa-Pineda B \& Sussel L. Ghrelin cells replace insulin-producing beta cells in two mouse models of pancreas development. PNAS $20041012924-2929$.

15 Sun Y, Asnicar M, Saha PK, Chan L \& Smith RG. Ablation of ghrelin improves the diabetic but not obese phenotype of ob/ob mice. Cell Metabolism 20063 379-386.

16 Ukkola O, Ravussin E, Jacobson P, Snyder EE, Chagnon M, Sjostrom L \& Bouchard C. Mutations in the preproghrelin/ghrelin gene associated with obesity in humans. Journal of Clinical Endocrinology and Metabolism 200186 3996-3999.

17 Korbonits M, Gueorguiev M, O'Grady E, Lecoeur C, Swan DC, Mein CA, Weill J, Grossman AB \& Froguel P. A variation in the ghrelin gene increases weight and decreases insulin secretion in tall, obese children. Journal of Clinical Endocrinology and Metabolism $2002874005-4008$.

18 Ukkola O, Ravussin E, Jacobson P, Perusse L, Rankinen T, Tschop M, Heiman ML, Leon AS, Rao DC, Skinner JS, Wilmore JH, Sjostrom L \& Bouchard C. Role of ghrelin polymorphisms in obesity based on three different studies. Obesity Research $200210782-791$.

19 Poykko S, Ukkola O, Kauma H, Savolainen MJ \& Kesaniemi YA. Ghrelin Arg 51Gln mutation is a risk factor for type 2 diabetes and hypertension in a random sample of middle-aged subjects. Diabetologia $2003 \mathbf{4 6} 455-458$.
20 Poykko SM, Kellokoski E, Horkko S, Kauma H, Kesaniemi YA \& Ukkola O. Low plasma ghrelin is associated with insulin resistance. hypertension, and the prevalence of type 2 diabetes. Diabetes 2003 52 2546-2553.

21 Baessler A, Hasinoff MJ, Fischer M, Reinhard W, Sonnenberg GE, Olivier M, Erdmann J, Schunkert H, Doering A, Jacob HJ, Comuzzie AG, Kissebah AH \& Kwitek AE. Genetic linkage and association of the growth hormone secretagogue receptor (ghrelin receptor) gene in human obesity. Diabetes 200554 259-267.

22 Mager U, Lindi V, Lindstrom J, Eriksson JG, Valle TT, Hamalainen H, Ilanne-Parikka P, Keinanen-Kiukaanniemi S, Tuomilehto J, Laakso M, Pulkkinen L \& Uusitupa M. Association of the Leu 72Met polymorphism of the ghrelin gene with the risk of type 2 diabetes in subjects with impaired glucose tolerance in the Finnish Diabetes Prevention Study. Diabetic Medicine 200623 685-689.

23 Shulman GI. Cellular mechanisms of insulin resistance. Journal of Clinical Investigation 2000106 171-176.

24 Petersenn S, Rasch AC, Penshorn M, Beil FU \& Schulte HM. Genomic structure and transcriptional regulation of the human growth hormone secretagogue receptor. Endocrinology 2001142 2649-2659.

25 Kanamoto N, Akamizu T, Tagami T, Hataya Y, Moriyama K, Takaya K, Hosoda H, Kojima M, Kangawa K \& Nakao K. Genomic structure and characterization of the $5^{\prime}$-flanking region of the human ghrelin gene. Endocrinology 2004145 4144-4153.

26 Vionnet N, Hani EH, Dupont S, Gallina S, Francke S, Dotte S, De Matos F, Durand E, Lepretre F, Lecoeur C, Gallina P, Zekiri L, Dina C \& Froguel P. Genomewide search for type 2 diabetessusceptibility genes in French whites: evidence for a novel susceptibility locus for early-onset diabetes on chromosome 3q27-qter and independent replication of a type 2-diabetes locus on chromosome 1q21-q24. American Journal of Human Genetics 200067 1470-1480.

27 Report of the Expert Committee on the Diagnosis and Classification of Diabetes Mellitus. Diabetes Care 199720 1183-1197.

28 Hercberg S, Preziosi P, Briancon S, Galan P, Triol I, Malvy D, Roussel AM \& Favier A. A primary prevention trial using nutritional doses of antioxidant vitamins and minerals in cardiovascular diseases and cancers in a general population: the SU.VI.MAX study - design, methods, and participant characteristics. Supplementation en VItamines et Mineraux AntioXydants. Controlled Clinical Trials $199819336-351$.

29 Lafay L, Basdevant A, Charles MA, Vray M, Balkau B, Borys JM, Eschwege E \& Romon M. Determinants and nature of dietary underreporting in a free-living population: the Fleurbaix Laventie Ville Sante (FLVS) Study. International Journal of Obesity and Related Metabolic Disorders 199721 567-573.

30 Garcia EA, Heude B, Petry CJ, Gueorguiev M, Hassan-Smith ZK, Spanou A, Ring SM, Dunger DB, Wareham N, Sandhu M, Ong KK \& Korbonits M. Ghrelin receptor gene polymorphisms and body size in children and adults. Journal of Clinical Endocrinology and Metabolism 200893 4158-4161.

31 Gueorguiev M, Wiltshire S, Garcia EA, Mein C, Lecoeur C, Kristen B, Allotey R, Hattersley AT, Walker M, O'Rahilly S, Froguel P, Grossman AB, McCarthy MI, Hitman GA \& Korbonits M. Examining the candidacy of ghrelin as a gene responsible for variation in adult stature in a United Kingdom population with type 2 diabetes. Journal of Clinical Endocrinology and Metabolism 200792 2201-2204.

32 Barrett JC, Fry B, Maller J \& Daly MJ. Haploview: analysis and visualization of $\mathrm{LD}$ and haplotype maps. Bioinformatics 200521 263-265.

33 de Bakker PI, Yelensky R, Pe'er I, Gabriel SB, Daly MJ \& Altshuler D. Efficiency and power in genetic association studies. Nature Genetics 200537 1217-1223.

34 Gueorguiev M, Lecoeur C, Meyre D, Weill J, Mein C, Grossman A, Froguel P \& Korbonits M 2003 Ghrelin and the growth hormone secretagogue receptor: a role in eating behaviour 
(Abstract). Digestive Hormones, Appetite and Energy Balance Symposium. Proceedings of the 85th Annual Meeting of the Endocrine Society 20031

35 Tregouet D \& Garelle V. A new JAVA interface implementation of THESIAS: Testing Haplotype Effects in Association Studies. Bioinformatics 200723 1038-1039.

36 Mager U, Degenhardt T, Pulkkinen L, Kolehmainen M, Tolppanen AM, Lindstrom J, Eriksson JG, Carlberg C, Tuomilehto J \& Uusitupa M. Variations in the ghrelin receptor gene associate with obesity and glucose metabolism in individuals with impaired glucose tolerance. PLOS ONE 20083 e2941.

37 Knight JC, Keating BJ, Rockett KA \& Kwiatkowski DP. In vivo characterization of regulatory polymorphisms by allele-specific quantification of RNA polymerase loading. Nature Genetics 2003 $33469-475$.
38 Lyssenko V, Jonsson A, Almgren P, Pulizzi N, Isomaa B, Tuomi T, Berglund G, Altshuler D, Nilsson P \& Groop L. Clinical risk factors, DNA variants, and the development of type 2 diabetes. New England Journal of Medicine 2008359 2220-2232.

39 Meigs JB, Shrader P, Sullivan LM, McAteer JB, Fox CS, Dupuis J, Manning AK, Florez JC, Wilson PW, D'Agostino RB Sr \& Cupples LA. Genotype score in addition to common risk factors for prediction of type 2 diabetes. New England Journal of Medicine $20083592208-2219$

Received 18 April 2009

Accepted 19 May 2009 